\title{
PENERAPAN MADM DENGAN METODE SAW UNTUK MENENTUKAN TARGET PROMOSI BERDASARKAN ASAL JURUSAN DI SEKOLAH
}

\author{
B.T. Sutrisno SP \\ Magister Teknologi Informasi \\ STMIK AKAKOM Yogyakarta \\ Email: denbambang@gmail.com \\ Widyastuti Andriyani \\ Magister Teknologi Informasi \\ STMIK AKAKOM Yogyakarta \\ Email:widya@akakom.ac.id
}

\begin{abstract}
ABSTRAK
Penerimaan Mahasiswa Baru (PMB) adalah proses yang sangat penting untuk merekrut mahasiswa baru, di mana jumlah mahasiswa sangat penting untuk operasional dan perencanaan pengembangan Perguruan Tinggi Swasta (PTS). Sebagai bagian dari PTS di Yogyakarta, Fakultas Kesehatan Universitas Jenderal Achmad Yani Yogyakarta berusaha meningkatkan jumlah mahasiswanya, dimana salah satunya dengan mengoptimalkan penentuan target promosi. Model Multiple Attribute Decision Making (MADM) dengan metode Simple Additive Weighting (SAW) dapat menghasilkan urutan peringkat yang dapat digunakan untuk menentukan keputusan terkait target promosi berdasarkan asal jurusan pada calon siswa di sekolah menengah, sehingga pembuat kebijakan Penerimaan Mahasiswa di Fakultas Kesehatan Universitas Jenderal Achmad Yani Yogyakarta dapat menentukan target promosi yang sesuai untuk meningkatkan jumlah mahasiswa baru.
\end{abstract}

Kata kunci: MADM, SAW, PMB, target promosi, universitas jenderal achmad yani yogyakarta

\begin{abstract}
New Student Admission (PMB) is a very important process for recruiting new students, where the number of students is very important for the operational and planning development of Private Universities (PTS). As part of private universities in Yogyakarta, the Faculty of Health of Universitas Jenderal Achmad Yani Yogyakarta, is trying to increase the number of students, one of them is by optimizing the determination of promotion targets. The Multiple Attribute Decision Making (MADM) model with the Simple Additive Weighting (SAW) method can produce ranking sequences that can be used to determine decisions related to promotion targets based on the origin of the majors in prospective students in secondary schools, so that policy makers for Student Admissions at t the Faculty of Health of Universitas Jenderal Achmad Yani Yogyakarta can determine the appropriate promotion target to increase the number of new students.
\end{abstract}

Keywords: MADM, SAW, promotion target, student admission, universitas jenderal achmad yani yogyakarta

\section{PENDAHULUAN}

Fakultas Kesehatan Universitas Jenderal Achmad Yani Yogyakarta dulunya bernama Sekolah Tinggi Ilmu Kesehatan Jenderal Achmad Yani Yogyakarta yang kemudian digabung menjadi bagian Universitas Jenderal Achmad Yani Yogyakarta, sebuah Perguruan Tinggi Swasta (PTS) di Yogyakarta yang berdiri berdasarkan Surat Keputusan Kementerian Riset dan Teknologi Pendidikan Tinggi Nomor 166/KPP///2018 tertanggal 2 Februari 2018. Fakultas Kesehatan Universitas Jenderal Achmad Yani Yogyakarta saat ini 
sedang berusaha meningkatkan jumlah mahasiswanya, karena sebagai PTS, jumlah mahasiswa sangat menentukan sangat menentukan untuk operasional pendidikan dan perencanaan pengembangan kampus kedepannya. Mahasiswa di Fakultas Kesehatan Universitas Jenderal Achmad Yani Yogyakarta berasal dari lulusan Sekolah Menegah Atas (SMA) dan Madarasah Aliyah (MA) dengan jurusan Ilmu Pengetahuan Alam (IPA), Ilmu Pengetahuan Sosial (IPS), Bahasa, dan Agama. Sedangkan yang berasal dari Sekolah Menengah Kejuruan (SMK) terdiri dari SMK jurusan kesehatan dan jurusan non kesehatan dari berbagai wilayah di Indonesia. Pada saat ini jumlah Mahasiswa Baru Fakultas Kesehatan Universitas Jenderal Achmad Yani Yogyakarta diketahui tidak stabil dan cenderung terus menurun setiap tahunnya, beberapa permasalahannya yang kemudian di identifikasi terkait dengan penentuan target promosi yang belum berdasarkan penelitian, sehingga penelitian ini bertujuan untuk menyajikan alternatif keputusan yang bisa diambil oleh pengambil kebijakan PMB dalam menentukan target sasaran promosi dengan menggunakan data mahasiswa periode 2014 sampai dengan 2018 pada 3 (tiga) Program Studi (Prodi), yaitu Prodi Keperawatan (S-1), Prodi Kebidanan (D-3), dan Prodi Rekam Medis dan Informasi Kesehatan (D-3).

Decision Support Systems (DSS) atau Sistem Pendukung Keputusan (SPK) adalah sebuah sistem yang memberikan kemampuan pemecahan masalah dan pengkomunikasian untuk masalah dengan kondisi semi terstruktur dan tak terstruktur. Sistem ini digunakan untuk membantu pengambilan keputusan dalam situasi semi terstruktur dan situasi yang tidak terstruktur, dimana tak seorangpun tahu secara pasti bagaimana keputusan seharusnya dibuat. DSS bertujuan untuk menyediakan informasi, membimbing, memberikan prediksi, dan mengarahkan kepada pengguna informasi agar dapat melakukan pengambilan keputusan secara tepat.

\section{METODOLOGI PENELITIAN}

\subsection{Metodologi Penelitian}

Metode yang digunakan dalam penelitian adalah Multiple Attribute Decision Making (MADM), yaitu suatu metode yang digunakan untuk mencari alternatif optimal dari sejumlah alternatif dengan kriteria tertentu dengan menentukan nilai bobot pada setiap atribut, yang kemudian dilanjutkan dengan proses perankingan untuk menyeleksi alternatif yang sudah diberikan [1]. Salah satu metode MADM adalah Simple Additive Weighting (SAW) yang dapat digunakan untuk penentuan pengambilan keputusan dengan menentukan bobot pada setiap atributnya, kemudian melakukan pemeringkatan untuk menyeleksi alternatif terbaik. Dalam metode SAW biasanya menggunakan konsep penjumlahan terbobot dari semua atribut di setiap alternatif. Metode SAW sering juga dikenal dengan istilah metode penjumlahan terbobot, dimana metode SAW mencari penjumlahan terbobot dari tingkat kinerja pada setiap alternatif pada semua atribut [2].

\subsection{Decision Support Systems (DSS)}

Secara umum, DSS di bangun oleh lima komponen utama yaitu Database Management, Model Management, Knowledge Base, User Interface, dan User yang dijelaskan sebagai berikut:

1. Data Management, merupakan segala bentuk aktivitas yang berhubungan dengan proses pengambilan, penyimpanan, dan pengaturan data-data yang relevan dan terkait dengan keputusan yang akan diambil. Komponen ini juga terkait dengan berbagai fungsi seperti keamanan data, integritas data, dan administrasi data yang berkaitan dengan DSS.

2. Model Management, merupakan seluruh aktivitas pengambilan, penyimpanan, dan pengaturan data dengan berbagai model kuantitatif, serta menyediakan kemampuan analisa dalam DSS.

3. Knowledge Base, merupakan aktivitas yang berkaitan dengan pendefinisian masalah sehingga dapat dihasilkan solusi sementara maupun final. Knowledge base merupakan 
komponen penting dalam DSS dimana data dan model diolah sehingga dapat menghasilkan bahan pertimbangan bagi user dalam mengambil keputusan.

4. User Interface, merupakan tampilan penghubung antara sistem dengan user, sehingga komponen- komponen sistem DSS dapat diakses dengan mudah oleh user dalam proses pengambilan keputusan. Semakin mudah sitem DSS dapat diakses oleh user, maka semakin berguna sistem tersebut.

5. User, merupakan pengguna dari sistem DSS yang memanfaatkan sistem untuk menyelesaikan permasalahan terkait pengambilan keputusan. Dalam penggunaan sistem DSS, kemampuan, ketrampilan, motivasi, dan pengetahuan pengguna sangat menentukan efektivitas dari sistem DSS.

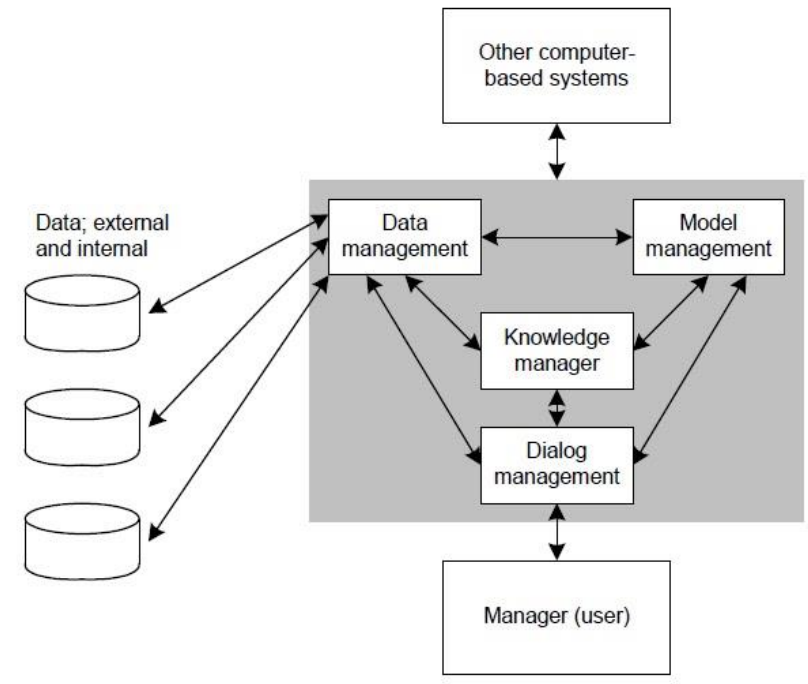

Gambar 1. Skema DSS [1]

\subsection{Pemodelan Multiple Attribute Decision Making (MADM)}

Secara umum MADM dapat didefinisikan sebagai berikut: misalkan $A=\{$ ai $\mid \mathrm{i}=1, \ldots, \mathrm{n}\}$ adalah himpunan alternatif-alternatif keputusan dan $\mathrm{C}=\{\mathrm{cj} \mid \mathrm{j}=1, \ldots, \mathrm{m}\}$ adalah himpunan tujuan yang diharapkan, maka akan ditentukan alternatif $\mathrm{x} 0$ yang memiliki derajat harapan tertinggi terhadap tujuan-tujuan yang relevan cj [3]. Sedangkan batasan tentang adanya beberapa fitur umum yang akan digunakan dalam MADM yaitu [4]:

1. Alternatif, adalah obyek-obyek yang berbeda dan memiliki kesempatan yang sama untuk dipilih oleh pengambil keputusan. Misalkan $\mathrm{A}=\{\mathrm{ai} \mid \mathrm{i}=1, \ldots, \mathrm{n}\}$ adalah himpunan alternatifalternatif keputusan.

2. Atribut, sering juga disebut sebagai karakteristik, komponen, atau kriteria keputusan. Meskipun pada kebanyakan kriteria bersifat satu level, namun tidak menutup kemungkinan adanya sub kriteria yang berhubungan dengan kriteria yang telah diberikan. Misalkan $C=\{c j$ $\mid \mathrm{j}=1, \ldots, \mathrm{m}\}$.

3. Konflik antar kriteria, beberapa kriteria biasanya mempunyai konflik antara satu dengan yang lainnya, misalnya kriteria keuntungan akan mengalami konflik dengan kriteria biaya.

4. Bobot keputusan, menunjukkan kepentingan relatif dari setiap kriteria. Akan dicari bobot kepentingan dari setiap kriteria. Pada MADM akan dicari bobot kepentingan dari setiap kriteria. Nilai bobot yang menunjukkan tingkat kepentingan relatif setiap atribut, diberikan sebagai $\mathrm{W}$ dimana $\mathrm{W}=(\mathrm{w} 1, \mathrm{w} 2, \ldots, \mathrm{wn})$. 
5. Masalah MADM adalah mengevaluasi $\mathrm{m}$ alternatif Ai $(\mathrm{i}=1,2, \ldots, \mathrm{m})$ terhadap sekumpulan atribut atau kriteria $\mathrm{Cj}(\mathrm{j}=1,2, \ldots, \mathrm{n})$, dimana setiap atribut saling tidak bergantung satu dengan yang lainnya.

6. Matriks keputusan, suatu matriks keputusan $\mathrm{X}$ yang berukuran $\mathrm{m} \times \mathrm{n}$, berisi elemen-elemen xij yang merepresentasikan rating dari alternatif $\mathrm{Ai}(\mathrm{i}=1,2, \ldots, \mathrm{m})$ terhadap $\mathrm{Cj}(\mathrm{j}=1,2, \ldots, \mathrm{n})$. Matriks keputusan setiap alternatif terhadap setiap altribut $\mathrm{X}$, diberikan sebagai:

$$
\mathrm{X}=\left[\begin{array}{cccc}
\mathrm{x}_{11} & \mathrm{x}_{12} & \cdots & \mathrm{x}_{1 \mathrm{n}} \\
\mathrm{x}_{21} & \mathrm{x}_{22} & \cdots & \mathrm{x}_{2 \mathrm{n}} \\
\vdots & \vdots & & \vdots \\
\mathrm{x}_{\mathrm{m} 1} & \mathrm{x}_{\mathrm{m} 2} & \cdots & \mathrm{x}_{\mathrm{mn}}
\end{array}\right]
$$

Dengan xij merupakan rating kinerja alternatif ke-i terhadap atribut ke-j.

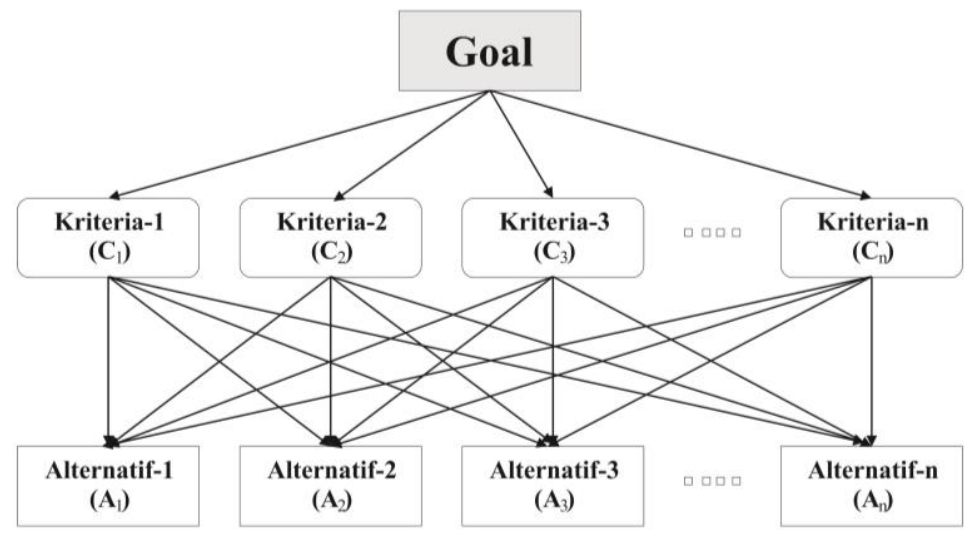

Gambar 2. Konsep MADM [5]

\subsection{Metode Simple Additive Weighting (SAW)}

Metode SAW yang sering juga dikenal istilah metode penjumlahan terbobot yang digunakan untuk mencari alternatif optimal dari sejumlah alternatif dengan kriteria tertentu. Secara umum, metode SAW digunakan untuk mencari penjumlahan terbobot dari rating kinerja pada setiap alternatif pada semua atribut. Metode SAW membutuhkan proses normalisasi matriks keputusan X ke suatu skala yang dapat diperbandingkan dengan semua rating alternatif yang ada. Formula untuk melakukan normalisasi tersebut adalah sebagai berikut [5]:

$$
r_{i j}=\left\{\begin{array}{l}
\frac{x_{i j}}{\operatorname{Max} x_{i j}} j i k a j \text { adalah atribut keuntungan (benefit) } \\
\frac{\operatorname{Min}_{i} x_{i j}}{x_{i j}} j i k a j \text { adalah atribut biaya }(\text { cost })
\end{array}\right.
$$

Dimana rij adalah rating kinerja ternormalisasi dari alternatif Ai pada atribut $\mathrm{Cj} ; \mathrm{i}=1,2, \ldots, \mathrm{m}$ dan $\mathrm{j}=1,2, \ldots, \mathrm{n}$. Nilai preferensi untuk setiap alternatif (Vi) diberikan sebagai:

$\mathrm{v} i=\sum_{j=1}^{n} w_{j} r_{i j}$

Nilai Vi yang lebih besar mengindikasikan bahwa alternatif Ai lebih terpilih. 


\subsection{Tahapan Penelitian}

Objek penelitian ini adalah data mahasiswa baru Fakultas Kesehatan Universitas Jenderal Achmad Yani Yogyakarta mulai tahun 2014 sampai tahun 2018. Adapun tahapan-tahapan dalam penelitian ini meliputi: (1) Pengambilan data mahasiswa baru Fakultas Kesehatan Universitas Jenderal Achmad Yani Yogyakarta berdasarkan asal jurusan di Sekolah, (2) Menetukan alternatif, kriteria, dan bobot data, (3) Penerapan Metode SAW terhadap data, dan (4) Menampilkan rekomendasi target promosi berdasarkan hasil pengolahan data.

\subsection{Tinjauan Pustaka}

Beberapa penelitian sebelumnya yang dijadikan referensi dalam penelitian ini adalah sebagai berikut:

a. Penelitian oleh Fifin Sonata pada tahun 2016 untuk mengimplementasikan Metode SAW dengan Proses Fuzzifikasi dalam Penilaian Kinerja Dosen [6], dimana hasil penelitian menunjukkan bahwa metode SAW dapat digunakan untuk membantu penentuan, rekomendasi, dan pertimbangan kinerja Dosen.

b. Penelitian tentang Pemilihan Hotel di Kota Palembang yang dilakukan oleh Dwi Citra Hartini, dkk. pada tahun 2013 [7], dimana hasil penelitian menunjukkan bahwa metode SAW dapat digunakan untuk membantu dan memberi kemudahan bagi pihak pengelola hotel dan dinas perijianan yang ada di Kota Palembang untuk berbagi informasi terbaru mengenai spesifikasi hotel mereka sehingga dapat memudahkan pelanggan dalam menentukan pilihan hotelnya.

c. Penelitian dari Kadek Bondan Noviada dkk. pada tahun 2015 tentang pembuatan Sistem Informasi Audit Mutu Internal (AMI) untuk mempermudah dan mempercepat pelaksanaan AMI di Universitas Pendidikan Ganesha [8], dimana hasilnya dapat mengimplementasikan pengambilan keputusan dengan metode SAW saat proses AMI di Universitas Pendidikan Ganesha dalam sistem berbasis web dan android.

d. Penelitian dari Ahmad Wildan Listyanto dkk. pada tahun 2018 tentang sistem pendukung keputusan untuk menetukan penerima zakat [9], dimana hasilnya dapat menyediakan alternatif pengambilan keputusan dalam menentukan penerima zakat di SMK Muhammadiyah Salaman.

e. Penelitian Hana Adela dkk. Pada tahun 2018 tentang sistem pendukung keputusan untuk menetukan pilihan penari [10], dimna hasilnya membuktikan bahwa metode SAW dapat menyediakan alternatif pengambilan keputusan dalam menentukan penari yang berkualitas berdasarkan kemampuan menari, kekuatan fisik, order, keterampilan, kepercayaan, cekatan, terdaftar, dan mempunyai sertifikat prestasi.

f. Penelitian Febri Haswan pada 2017 tentang sistem pendukung keputusan untuk memlilih anggota Satpol PP baru [11], dimana hasilnya metode SAW juga terbukti dapat menyediakan alternatif pengambilan keputusan untuk memlilih anggota Satpol PP baru.

g. Penelitian Mohammad Hasan Aghdaie dan Maryam Alimardani pada tahun 2015 [12] yang secara spesifik untuk penentuan target market, dengan judul penelitian Target market selection based on market segment evaluation: a multiple attribute decision making approach dimana hasil penelitiannya menunjukan bahwa model MADM mampu menunjukan pilihan yang dapat diambil pengambil keputusan dalam menentukan target market.

\section{HASIL DAN PEMBAHASAN}

\subsection{Penetuan Kriteria dan Alternatif}


Tahap pertama dengan menentukan kriteria berdasarkan data mahasiswa baru Fakultas Kesehatan Universitas Jenderal Achmad Yani Yogyakarta mulai tahun 2014 sampai tahun 2018, dimana diketahui 7 asal informasi terbanyak calon mahasiswa baru Fakultas Kesehatan Universitas Jenderal Achmad Yani Yogyakarta yang diinisialkan dengan $\mathrm{C} 1$ sampai dengan C7 sebagai berikut: $\mathrm{C} 1$ = Mahasiswa, $\mathrm{C} 2=$ Teman, $\mathrm{C} 3=$ Kakak Kelas, $\mathrm{C} 4=$ Website, $\mathrm{C} 5=$ Brosur, C6 = Guru BK, dan C7 = Datang ke Kampus. Selain kriteria asal informasi diatas, berdasarkan data mahasiswa baru Fakultas Kesehatan Universitas Jenderal Achmad Yani Yogyakarta mulai tahun 2014 sampai tahun 2018 juga terdapat data asal jurusan di Sekolah yang kemudian di tetapkan sebagai alternatif yang diinisialkan dengan A1 sampai dengan A6 sebagai berikut: A1 = Jurusan SMK Non Kesehatan, A2 = Jurusan SMK Kesehatan, A3 = Jurusan IPS, A4 = Jurusan IPA, A5 = Jurusan Bahasa, A6 = Jurusan Agama. Dari kriteria dan alternatif di atas, kemudian dibuat sebuah pemodelan MADM untuk menentukan Goal sebagai berikut:

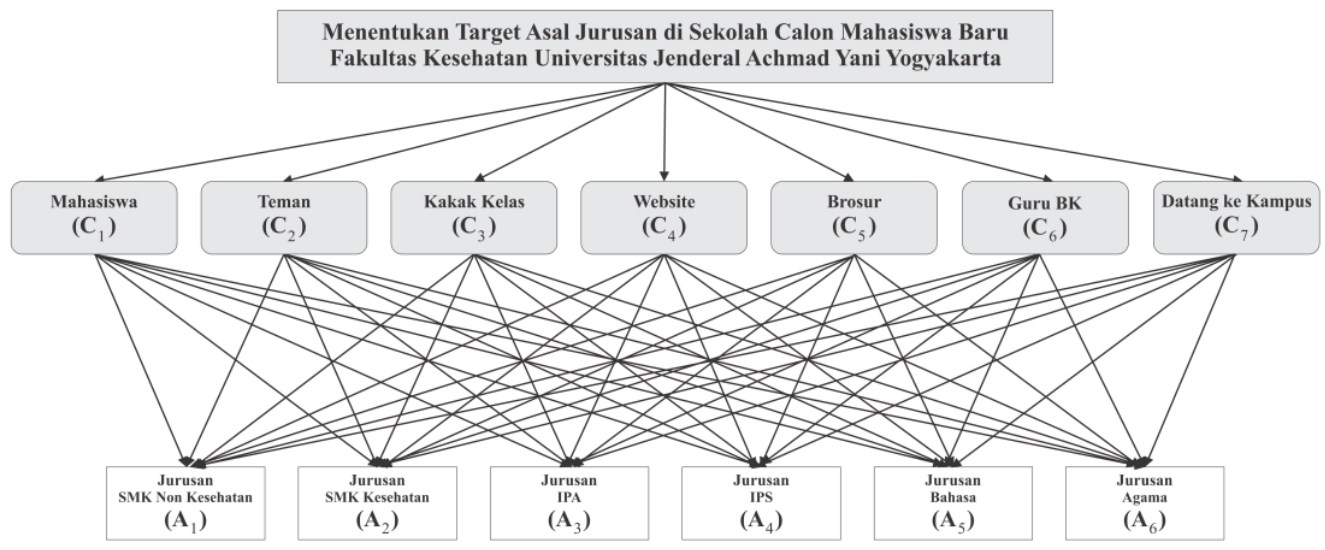

Gambar 3. Pemodelan Goal MADM

\subsection{Penentuan Bobot}

Dalam proses penetuan target promosi berdasarkan asal jurusan di sekolah calon mahasiswa baru, selain memerlukan kriteria-kriteria yang akan dijadikan bahan pertimbangan dan perhitungan, juga diperlukan penentuan bobot dari masing-masing kriteria. Berdasarkan data mahasiswa baru Fakultas Kesehatan Universitas Jenderal Achmad Yani Yogyakarta tahun 2014 sampai tahun 2018 diketahui profil per-kriteria per-tahun yang digambarkan dalam grafik sebagai berikut:

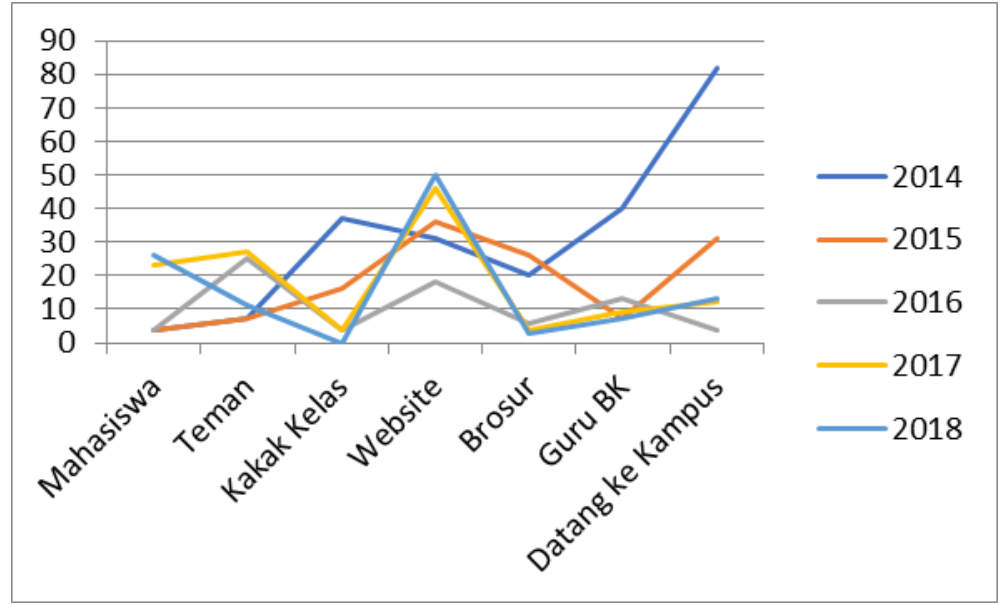

Gambar 4. Grafik Kriteria per Tahun 
Stakeholder PMB Fakultas Kesehatan Universitas Jenderal Achmad Yani Yogyakarta menentukan atribut dan bobot dari masing-masing kriteria diatas sebagai berikut:

a. Kriteria mahasiswa bernilai benefit karena memberikan keuntungan bagi PMB Fakultas Kesehatan Universitas Jenderal Achmad Yani Yogyakarta, dimana selain tidak menimbulkan biaya, mahasiswa merupakan salah satu yang paling efektif sebagai agen marketing.

b. Kriteria teman bernilai benefit karena memberikan keuntungan bagi PMB Fakultas Kesehatan Universitas Jenderal Achmad Yani Yogyakarta, dimana selain tidak menimbulkan biaya, kriteria teman calon mahasiswa menjadi yang salah satu yang mereferensikan untuk berkuliah di Fakultas Kesehatan Universitas Jenderal Achmad Yani Yogyakarta.

c. Kriteria kaka kelas bernilai benefit karena memberikan keuntungan bagi PMB Fakultas Kesehatan Universitas Jenderal Achmad Yani Yogyakarta, dimana selain tidak menimbulkan biaya, kriteria kakak kelas calon mahasiswa menjadi yang salah satu yang mereferensikan dan memberikan pengaruh kepada calon untuk berkuliah di Fakultas Kesehatan Universitas Jenderal Achmad Yani Yogyakarta.

d. Kriteria website bernilai benefit karena memberikan keuntungan bagi PMB Fakultas Kesehatan Universitas Jenderal Achmad Yani Yogyakarta, dimana selain tidak menimbulkan biaya promosi yang signifikan, website menjadi yang terbanyak direferensi calon mahasiswa sebelum menentukan untuk berkuliah di Fakultas Kesehatan Universitas Jenderal Achmad Yani Yogyakarta.

e. Kriteria brosur bernilai cost karena menimbulkan biaya bagi PMB Fakultas Kesehatan Universitas Jenderal Achmad Yani Yogyakarta, dimana diperlukan biaya yang cukup signifikan untuk mencetak brosur.

f. Kriteria guru BK bernilai cost karena menimbulkan biaya bagi PMB Fakultas Kesehatan Universitas Jenderal Achmad Yani Yogyakarta, dimana diperlukan biaya untuk menjalin dan memelihara kerja sama dengan para guru BK di Sekolah.

g. Kriteria datang ke kampus bernilai benefit karena sangat memberikan keuntungan bagi PMB Fakultas Kesehatan Universitas Jenderal Achmad Yani Yogyakarta, dimana selain tidak menimbulkan biaya promosi, kriteria datang ke kampus menjadi saat yang menentukan dalam menyakinkan calon mahasiswa untuk menentukan berkuliah di Fakultas Kesehatan Universitas Jenderal Achmad Yani Yogyakarta.

Dari uraian kriteria diatas, Stakeholder PMB Fakultas Kesehatan Universitas Jenderal Achmad Yani Yogyakarta kemudian memberikan bobot untuk masing-masing kriteria sebagai berikut:

Tabel 1. Penetuan Atribut dan Bobot

\begin{tabular}{|l|l|c|c|}
\hline No & Kriteria & Atribut & Nilai Bobot (W) \\
\hline 1 & Mahasiswa & Benefit & 10 \\
\hline 2 & Teman & Benefit & 10 \\
\hline 3 & Kakak Kelas & Benefit & 10 \\
\hline 4 & Website & Benefit & 20 \\
\hline 5 & Brosur & Cost & 10 \\
\hline 6 & Guru BK & Cost & 10 \\
\hline 7 & Datang ke Kampus & Benefit & 30 \\
\hline
\end{tabular}

Total w harus sama dengan 1 atau $100 \%$ karena dalam sebuah keputusan, variabel-variabel lain yang mempengaruhi keputusan tersebut harus berjumlah 1 .

\subsection{Pembahasan}

Dalam proses selanjutnya, dengan membuat membuat tabel rating kecocokan kinerja dari setiap alternatif berdasarkan data mahasiswa baru Fakultas Kesehatan Universitas Jenderal 
Achmad Yani Yogyakarta mulai tahun 2014 sampai tahun 2018 seperti dalam tabel berikut:

Tabel 2. Data Kriteria dan Alternatif

\begin{tabular}{|c|c|c|c|c|c|c|c|}
\hline Alternatif/Kriteria & C1 & C2 & C3 & C4 & C5 & C6 & C7 \\
\hline A1 & 19 & 28 & 20 & 57 & 15 & 6 & 40 \\
\hline $\mathbf{A 2}$ & 22 & 27 & 14 & 94 & 11 & 33 & 30 \\
\hline $\mathbf{A 3}$ & 39 & 44 & 41 & 87 & 20 & 49 & 86 \\
\hline $\mathbf{A 4}$ & 61 & 77 & 61 & 181 & 59 & 76 & 142 \\
\hline $\mathbf{A 5}$ & 2 & 1 & 2 & 1 & 0 & 3 & 5 \\
\hline $\mathbf{A 6}$ & 2 & 1 & 1 & 1 & 3 & 1 & 0 \\
\hline
\end{tabular}

Setelah proses tabulasi data, kemudian di buat suatu tingkat kepentingan berdasarkan nilai range nilai jumlah data yang telah ditentukan oleh stakeholder PMB Fakultas Kesehatan Universitas Jenderal Achmad Yani Yogyakarta sebagai berikut:

Tabel 3. Nilai Range Jumlah Data

\begin{tabular}{|c|c|}
\hline Range Jumlah & Nilai \\
\hline$>81$ & 1 \\
\hline $51-80$ & 0.75 \\
\hline $26-50$ & 0.5 \\
\hline$<25$ & 0.25 \\
\hline
\end{tabular}

Setelah dilakukan kriteria, alternatif, dan bobot dari data mahasiswa baru Fakultas Kesehatan Universitas Jenderal Achmad Yani Yogyakarta mulai tahun 2014 sampai tahun 2018 diketahui, selanjutnya adalah merubah data berdasarkan nilai range yang telah ditetapkan sebagaimana terlihat pada tabel berikut

Tabel 4. Penetuan Rating Kecocokan Data dari Setiap Alternatif pada Setiap Kriteria

\begin{tabular}{|c|c|c|c|c|c|c|c|}
\hline Alternatif/Kriteria & C1 & C2 & C3 & C4 & C5 & C6 & C7 \\
\hline A1 & 0.25 & 0.5 & 0.25 & 0.75 & 0.25 & 0.25 & 0.5 \\
\hline $\mathbf{A 2}$ & 0.25 & 0.5 & 0.25 & 1 & 0.25 & 0.5 & 0.5 \\
\hline $\mathbf{A 3}$ & 0.5 & 0.5 & 0.5 & 1 & 0.25 & 0.5 & 1 \\
\hline $\mathbf{A 4}$ & 0.75 & 0.75 & 0.75 & 1 & 0.75 & 0.75 & 1 \\
\hline $\mathbf{A 5}$ & 0.25 & 0.25 & 0.25 & 0.25 & 0.25 & 0.25 & 0.25 \\
\hline $\mathbf{A 6}$ & 0.25 & 0.25 & 0.25 & 0.25 & 0.25 & 0.25 & 0.25 \\
\hline
\end{tabular}

Proses selanjutnya adalah melaksanakan pengujian dengan metode SAW untuk menentukan target promosi dengan memasukan data ke dalam matriks keputusan X sebagai berikut:

$$
\mathrm{X}=\left\{\begin{array}{ccccccc}
0.25 & 0.5 & 0.25 & 0.75 & 0.25 & 0.25 & 0.5 \\
0.25 & 0.5 & 0.25 & 1 & 0.25 & 0.5 & 0.5 \\
0.5 & 0.5 & 0.5 & 1 & 0.25 & 0.5 & 1 \\
0.75 & 0.75 & 0.75 & 1 & 0.75 & 0.75 & 1 \\
0.25 & 0.25 & 0.25 & 0.25 & 0.25 & 0.25 & 0.25 \\
0.25 & 0.25 & 0.25 & 0.25 & 0.25 & 0.25 & 0.25
\end{array}\right\}
$$

Matrik keputusan X diatas akan menjadi tolok ukur awal untuk mendapatkan perhitungan setiap kriteria terhadap alternatif. Tahap selanjutnya adalah melakukan proses normalisasi dari matriks $\mathrm{X}$ menjadi matriks $\mathrm{r}$ menggunakan rumus:

$$
r_{i j}=\left\{\begin{array}{l}
\frac{x_{i j}}{\operatorname{Max} x_{i j}} \text { jika } j \text { adalah atribut keuntungan (benefit) } \\
\frac{\operatorname{Min}_{i} x_{i j}}{x_{i j}} \text { jika } j \text { adalah atribut biaya }(\text { cost })
\end{array}\right.
$$


Kriteria $\mathrm{C} 1$ sampai dengan $\mathrm{C} 4$ dan $\mathrm{C} 7$ bernilai benefit yang artinya nilai-nilai pada nilai tersebut memberikan pengaruh keuntungan bagi promosi Fakultas Kesehatan Universitas Jenderal Achmad Yani Yogyakarta, sedangkan kriteria C5 dan C6 bernilai cost yang artinya nilai-nilai pada nilai tersebut menimbulkan biaya bagi promosi Fakultas Kesehatan Universitas Jenderal Achmad Yani Yogyakarta. Adapun proses normalisasi matriks X menjadi r sebagai berikut:

1. Normalisasi terhadap $\mathrm{C} 1$ yang berpengaruh kepada benefit

$$
\begin{aligned}
& \text { r } 1.1=\frac{0.25}{\operatorname{Max}\{0.25,0.25,0.5,0.75,0.25,0.25\}}=\frac{0.25}{0.75}=0.333333333 \\
& \text { r } 1.2=\frac{0.25}{\operatorname{Max}\{0.25,0.25,0.5,0.75,0.25,0.25\}}=\frac{0.25}{0.75}=0.333333333 \\
& \text { r } 1.3=\frac{0.5}{\operatorname{Max}\{0.25,0.25,0.5,0.75,0.25,0.25\}}=\frac{0.5}{0.75}=0.666666667 \\
& \text { r } 1.4=\frac{0.75}{\operatorname{Max}\{0.25,0.25,0.5,0.75,0.25,0.25\}}=\frac{0.75}{0.75}=1 \\
& \text { r } 1.5=\frac{0.25}{\operatorname{Max}\{0.25,0.25,0.5,0.75,0.25,0.25\}}=\frac{0.25}{0.75}=0.333333333 \\
& \text { r } 1.6=\frac{0.25}{\operatorname{Max}\{0.25,0.25,0.5,0.75,0.25,0.25\}}=\frac{0.25}{0.75}=0.333333333
\end{aligned}
$$

2. Normalisasi terhadap $\mathrm{C} 2$ yang berpengaruh kepada benefit

$$
\begin{aligned}
& \text { r } 2.1=\frac{0.25}{\operatorname{Max}\{0.25,0.25,0.5,0.75,0.25,0.25\}}=\frac{0.25}{0.75}=0.333333333 \\
& \text { r } 2.2=\frac{0.25}{\operatorname{Max}\{0.25,0.25,0.5,0.75,0.25,0.25\}}=\frac{0.25}{0.75}=0.333333333 \\
& \text { r } 2.3=\frac{0.5}{\operatorname{Max}\{0.25,0.25,0.5,0.75,0.25,0.25\}}=\frac{0.5}{0.75}=0.6666666667 \\
& \text { r } 2.4=\frac{0.75}{\operatorname{Max}\{0.25,0.25,0.5,0.75,0.25,0.25\}}=\frac{0.75}{0.75}=1 \\
& \text { r } 2.5=\frac{0.25}{\operatorname{Max}\{0.25,0.25,0.5,0.75,0.25,0.25\}}=\frac{0.25}{0.75}=0.333333333 \\
& \text { r 2.6 }=\frac{0.25}{\operatorname{Max}\{0.25,0.25,0.5,0.75,0.25,0.25\}}=\frac{0.25}{0.75}=0.333333333
\end{aligned}
$$

3. Normalisasi terhadap C3 yang berpengaruh kepada benefit

$$
\begin{aligned}
& \text { r } 3.1=\frac{0.25}{\operatorname{Max}\{0.25,0.25,0.5,0.75,0.25,0.25\}}=\frac{0.25}{0.75}=0.333333333 \\
& \text { r 3.2 }=\frac{0.25}{\operatorname{Max}\{0.25,0.25,0.5,0.75,0.25,0.25\}}=\frac{0.25}{0.75}=0.333333333 \\
& \text { r } 3.3=\frac{0.5}{\operatorname{Max}\{0.25,0.25,0.5,0.75,0.25,0.25\}}=\frac{0.5}{0.75}=0.666666667 \\
& \text { r 3.4 }=\frac{0.75}{\operatorname{Max}\{0.25,0.25,0.5,0.75,0.25,0.25\}}=\frac{0.75}{0.75}=1 \\
& \text { r 3.5 }=\frac{0.25}{\operatorname{Max}\{0.25,0.25,0.5,0.75,0.25,0.25\}}=\frac{0.25}{0.75}=0.333333333 \\
& \text { r 3.6 }=\frac{0.25}{\operatorname{Max}\{0.25,0.25,0.5,0.75,0.25,0.25\}}=\frac{0.25}{0.75}=0.333333333
\end{aligned}
$$

4. Normalisasi terhadap $\mathrm{C} 4$ yang berpengaruh kepada benefit 


$$
\begin{aligned}
& \text { r } 4.1=\frac{0.75}{\operatorname{Max}\{0.25,0.25,0.5,0.75,0.25,0.25\}}=\frac{0.75}{1}=0.75 \\
& \text { r } 4.2=\frac{1}{\operatorname{Max}\{0.25,0.25,0.5,0.75,0.25,0.25\}}=\frac{1}{1}=1 \\
& \text { r } 4.3=\frac{1}{\operatorname{Max}\{0.25,0.25,0.5,0.75,0.25,0.25\}}=\frac{1}{1}=1 \\
& \text { r } 4.4=\frac{1}{\operatorname{Max}\{0.25,0.25,0.5,0.75,0.25,0.25\}}=\frac{1}{1}=1 \\
& \text { r } 4.5=\frac{0.25}{\operatorname{Max}\{0.25,0.25,0.5,0.75,0.25,0.25\}}=\frac{0.25}{1}=0.25 \\
& \text { r } 4.6=\frac{0.25}{\operatorname{Max}\{0.25,0.25,0.5,0.75,0.25,0.25\}}=\frac{0.25}{1}=0.25
\end{aligned}
$$

5. Normalisasi terhadap C5 yang berpengaruh kepada cost

$$
\begin{aligned}
& \text { r 5.1 }=\frac{0.25}{\operatorname{Min}\{0.25,0.25,0.25,0.75,0.25,0.25\}}=\frac{0.25}{0.25}=1 \\
& \text { r 5.2 }=\frac{0.25}{\operatorname{Min}\{0.25,0.25,0.25,0.75,0.25,0.25\}}=\frac{0.25}{0.25}=1 \\
& \text { r 5.3 }=\frac{0.25}{\operatorname{Min}\{0.25,0.25,0.25,0.75,0.25,0.25\}}=\frac{0.25}{0.25}=1 \\
& \text { r 5.4 }=\frac{0.75}{\operatorname{Min}\{0.25,0.25,0.25,0.75,0.25,0.25\}}=\frac{0.75}{0.25}=3 \\
& \text { r 5.5 }=\frac{0.25}{\operatorname{Min}\{0.25,0.25,0.25,0.75,0.25,0.25\}}=\frac{0.25}{0.25}=1 \\
& \text { r 5.6 }=\frac{0.25}{\operatorname{Min}\{0.25,0.25,0.25,0.75,0.25,0.25\}}=\frac{0.25}{0.25}=1
\end{aligned}
$$

6. Normalisasi terhadap C6 yang berpengaruh kepada cost

$$
\begin{aligned}
& \text { r 6.1 }=\frac{0.25}{\operatorname{Min}\{0.25,0.25,0.25,0.75,0.25,0.25\}}=\frac{0.25}{0.25}=1 \\
& \text { r } 6.2=\frac{0.5}{\operatorname{Min}\{0.25,0.25,0.25,0.75,0.25,0.25\}}=\frac{0.5}{0.25}=2 \\
& \text { r } 6.3=\frac{0.5}{\operatorname{Min}\{0.25,0.25,0.25,0.75,0.25,0.25\}}=\frac{0.5}{0.25}=2 \\
& \text { r } 6.4=\frac{0.75}{\operatorname{Min}\{0.25,0.25,0.25,0.75,0.25,0.25\}}=\frac{0.75}{0.25}=3 \\
& \text { r } 6.5=\frac{0.25}{\operatorname{Min}\{0.25,0.25,0.25,0.75,0.25,0.25\}}=\frac{0.25}{0.25}=1 \\
& \text { r 6.6 }=\frac{0.25}{\operatorname{Min}\{0.25,0.25,0.25,0.75,0.25,0.25\}}=\frac{0.25}{0.25}=1
\end{aligned}
$$

7. Normalisasi terhadap $\mathrm{C} 7$ yang berpengaruh kepada benefit 


$$
\begin{aligned}
& \text { r 7.1 }=\frac{0.5}{\operatorname{Max}\{0.5,0.5,1,1,0.25,0.25\}}=\frac{0.5}{1}=0.5 \\
& \text { r 7.2 }=\frac{0.5}{\operatorname{Max}\{0.5,0.5,1,1,0.25,0.25\}}=\frac{0.5}{1}=0.5 \\
& \text { r 7.3 }=\frac{1}{\operatorname{Max}\{0.5,0.5,1,1,0.25,0.25\}}=\frac{1}{1}=1 \\
& \text { r 7.4 }=\frac{1}{\operatorname{Max}\{0.5,0.5,1,1,0.25,0.25\}}=1 \\
& \text { r 7.5 }=\frac{0.25}{\operatorname{Max}\{0.5,0.5,1,1,0.25,0.25\}}=\frac{0.25}{1}=0.25 \\
& \text { r 7.6 }=\frac{0.25}{\operatorname{Max}\{0.5,0.5,1,1,0.25,0.25\}}=\frac{0.25}{1}=0.25
\end{aligned}
$$

Dari perhitungan terhadap C1 sampai dengan C7 menghasilkan sebuah matriks ternormalisasi r sebagai berikut:

$$
\mathbf{r}=\left\{\begin{array}{ccccccc}
0.333333333 & 0.333333333 & 0.333333333 & 0.75 & 1 & 1 & 0.5 \\
0.333333333 & 0.333333333 & 0.333333333 & 1 & 1 & 2 & 0.5 \\
0.666666667 & 0.666666667 & 0.666666667 & 1 & 1 & 2 & 1 \\
1 & 1 & 1 & 1 & 3 & 3 & 1 \\
0.333333333 & 0.333333333 & 0.333333333 & 0.25 & 1 & 1 & 0.25 \\
0.333333333 & 0.333333333 & 0.333333333 & 0.25 & 1 & 1 & 0.25
\end{array}\right\}
$$

Setelah matriks normalisasi $r$ didapat, maka langkah selajutnya adalah melakukan perangkingan menggunakan bobot yang telah di tetapkan. Tahapan ini merupakan tahapan akhir dalam menentukan target promosi berdasarkan asal jurusan di Sekolah calon mahasiswa. Dari tahap ini akan diperolah asal jurusan mana yang menduduki posisi rangking tertinggi sampai terendah. Rangking asal jurusan tertinggi nantinya dapat dijadikan solusi bagi stakeholder PMB Fakultas Kesehatan Universitas Jenderal Achmad Yani Yogyakarta dalam mengambil kebijakan terkait menentukan target asal jurusan di Sekolah calon mahasiswa. Matriks $\mathrm{r}$ ternormalisasi merupakan data yang akan diolah pada proses perangkingan menggunakan rumus SAW dengan dan diperoleh nilai kinerja sebagai berikut:

$$
\begin{aligned}
& \text { 1. } \mathrm{V} 1=(10 \mathrm{x} 0.333333333)+(10 \mathrm{x} 0.333333333)+(10 \mathrm{x} 0.333333333)+(20 \mathrm{x} 0.75)+(10 \mathrm{x} 1) \\
& +(10 \times 1)+(30 \times 0.5)=60 \\
& \text { 2. } \mathrm{V} 2=(10 \mathrm{x} 0.333333333)+(10 \mathrm{x} 0.333333333)+(10 \mathrm{x} 0.333333333)+(20 \times 1)+(10 \mathrm{x} 1) \\
& +(10 \times 2)+(30 \times 0.5)=75 \\
& \text { 3. } \mathrm{V} 3=(10 \mathrm{x} 0.666666667)+(10 \mathrm{x} 0.666666667)+(10 \mathrm{x} 0.666666667)+(20 \mathrm{x} 1)+(10 \mathrm{x} 1) \\
& +(10 \times 2)+(30 \times 1)=100 \\
& \text { 4. } \mathrm{V} 4=(10 \times 1)+(10 \times 1)+(10 \times 1)+(20 \times 1)+(10 \times 3) \\
& +(10 \times 3)+(30 \times 1)=140 \\
& \text { 5. } \mathrm{V} 5=(10 \mathrm{x} 0.333333333)+(10 \mathrm{x} 0.333333333)+(10 \mathrm{x} 0.333333333)+(20 \mathrm{x} 0.25)+(10 \times 1) \\
& +(10 \times 1)+(30 \times 0.25)=42.5 \\
& \text { 6. } \mathrm{V} 6=(10 \mathrm{x} 0.333333333)+(10 \mathrm{x} 0.333333333)+(10 \mathrm{x} 0.333333333)+(20 \mathrm{x} 0.25)+(10 \mathrm{x} 1) \\
& +(10 \times 1)+(30 \times 0.25)=42.5
\end{aligned}
$$

Hasil akhir dari tahapan penelitian yang telah dilakukan menghasilkan nilai dalam tabel sebagai berikut:

Tabel 5. Hasil Perangkingan Asal Jurusan di Sekolah Mahasiswa Baru

\begin{tabular}{|l|c|}
\hline Alternatif Target Promosi & Total \\
\hline Jurusan SMK Non Kesehatan & 60 \\
\hline Jurusan SMK Kesehatan & 75 \\
\hline Jurusan IPS & 100 \\
\hline
\end{tabular}




\begin{tabular}{|l|c|}
\hline Jurusan IPA & 140 \\
\hline Jurusan Bahasa & 42.5 \\
\hline Jurusan Agama & 42.5 \\
\hline
\end{tabular}

Dari tabel hasil pengujian diatas, alternatif ke-4 menunjukkan nilai tertinggi yang berarti alternatif ke-4 merupakan Asal Jurusan di Sekolah yang paling prospek menjadi target promosi PMB Fakultas Kesehatan Universitas Jenderal Achmad Yani Yogyakarta. Sedangkan alternatif ke6 menunjukkan nilai terendah yang berarti alternatif ke-6 merupakan Asal Jurusan di Sekolah yang paling tidak prospek menjadi target promosi PMB Fakultas Kesehatan Universitas Jenderal Achmad Yani Yogyakarta. Urutan target promosi berdasarkan asal jurusan di Sekolah digambarkan dalam table berikut:

Tabel 6. Rangking Target Promosi Berdasarkan Asal Jurusan di Sekolah

\begin{tabular}{|l|c|c|}
\hline Alternatif Target Promosi & Total & Rangking \\
\hline Jurusan IPA & 140 & 1 \\
\hline Jurusan IPS & 100 & 2 \\
\hline Jurusan SMK Kesehatan & 75 & 3 \\
\hline Jurusan SMK Non Kesehatan & 60 & 4 \\
\hline Jurusan Bahasa & 42.5 & 5 \\
\hline Jurusan Agama & 42.5 & 6 \\
\hline
\end{tabular}

\section{KESIMPULAN}

Dari hasil penelitian ini maka dapat disimpulkan bahwa model Multiple Attribute Decision Making (MADM) dengan metode Simple Additive Weighting (SAW) dapat digunakan untuk menentukan target asal jurusan di Sekolah calon mahasiswa Fakultas Kesehatan Universitas Jenderal Achmad Yani Yogyakarta dengan cara penjumlahan terbobot dari rating kinerja pada setiap alternatif pada semua atribut (kriteria) yang menghasilkan urutan rangking dari mulai yang teratas sampai terbawah. Dengan demikian, maka para pengambil kebijakan PMB Fakultas Kesehatan Universitas Jenderal Achmad Yani Yogyakarta dapat mempertimbangkan asal jurusan di Sekolah dalam menentukan persyaratan calon mahasiswa yang akan mendaftar, sehingga target mahasiswa di Fakultas Kesehatan Universitas Jenderal Achmad Yani Yogyakarta dapat tercapai.

Saran untuk kedepannya, penelitian ini masih dalam bentuk perhitungan, sehingga dapat dikembangkan lebih lanjut dalam bentuk aplikasi yang dapat dengan mudah di akses para pengambil kebijakan secara cepat, sehingga dapat memutuskan secara tepat terkait persyaratan PMB Fakultas Kesehatan Universitas Jenderal Achmad Yani Yogyakarta.

\section{UCAPAN TERIMA KASIH}

Terima kasih untuk Fakultas Kesehatan Universitas Jenderal Achmad Yani Yogyakarta yang telah memberikan kesempatan kepada kami untuk mengolah data PMB sehingga penelitian ini dapat terlaksana dengan baik.

\section{DAFTAR PUSTAKA}

[1] M. N. Sutoyo, "Implementasi Metode MADM Model Yager untuk Seleksi Penerima Beasiswa PPA," JUITA J. Inform., 2018, doi: 10.30595/juita.v5i2.1630.

[2] R. MUNADI, M. MUKHROJI, S. SYAHRIAL, and E. D. MEUTIA, "Penerapan Multiple Attribute Decision Making dengan Metode Simple Additive Weighting untuk Pemeringkatan Kerentanan Keamanan Website," ELKOMIKA J. Tek. Energi Elektr. Tek. Telekomun. Tek. Elektron., 2018, doi: 10.26760/elkomika.v6i2.194. 
[3] H.-J. Zimmermann, Fuzzy Set Theory—and Its Applications. 2001.

[4] M. A. Mude, "Perbandingan Metode SAW dan TOPSIS pada kasus UMKM," Ilk. J. Ilm., 2016, doi: 10.33096/ilkom.v8i2.49.76-81.

[5] S. H. Kusumadewi, "Fuzzy Multi-Attribute Decision Making (Fuzzy MADM)," Graha Ilmu Yogyakarta, 2006.

[6] F. Sonata, "Implementasi Metode Simple Additive Weighting (Saw) dengan Proses Fuzzifikasi dalam Penilaian Kinerja Dosen," J. Teknol. Inf. dan Komun., 2016.

[7] E. L. Ruskan, A. Ibrahim, and D. C. Hartini, "SISTEM PENDUKUNG KEPUTUSAN PEMILIHAN HOTEL DI KOTA PALEMBANG DENGAN METODE SIMPLE ADDITIVE WEIGHTING (SAW)," J. Sist. Inf., 2013.

[8] K. Bondan, I. Made, and I. Made, "AMI Information System of Ganesha University of Education with Decision Support System," Int. J. Comput. Appl., 2015, doi: 10.5120/ijca2015907469.

[9] A. W. Listyanto, K. Kusrini, and S. Sudarmawan, "Determination of receipt of UPZ assistance using the SAW method," Int. J. Artif. Intell. Informatics, 2018, doi: 10.33292/ijarlit.v1i1.9.

[10] H. Adela, K. Azmi Jasmi, B. Basiron, M. Huda, and A. Maseleno, "Selection of dancer member using simple additive weighting," Int. J. Eng. Technol., 2018, doi: 10.14419/ijet.v7i3.11983.

[11] F. Haswan, "Decision Support System For Election Of Members Unit Patients Pamong Praja," Int. J. Artif. Intell. Res., 2017, doi: 10.29099/ijair.v1i1.14.

[12] M. H. Aghdaie and M. Alimardani, "Target market selection based on market segment evaluation: A multiple attribute decision making approach," Int. J. Oper. Res., 2015, doi: 10.1504/IJOR.2015.072231. 